\title{
ОСОБЛИВОСТІ ТЕХНОГЕННОГО ВПЛИВУ НА ДОВКІЛЛЯ ХЕРСОНСЬКОЇ ОБЛАСТІ
}

Херсонська область територіально належить до регіонів Північно-Західного Причорномор'я. Херсонщина має унікальний рекреаційний потенціал. При цьому промисловий комплекс регіону формують понад 200 підприємств різних галузей. В області існують певні екологічні проблеми, що призводять до виникнення несприятливих екологічних ситуацій (відведення земельних ділянок під полігони твердих побутових відходів, умови та стан зберігання непридатних для використання пестицидів; очисні споруди і каналізаційні мережі населених пунктів області тощо). Для оцінювання особливостей техногенного впливу на довкілля Херсонської області в роботі застосовано принцип розрахунку модуля техногенного навантаження. Розраховували окремі модулі на складники довкілля (повітряний басейн, водні об'єкти, геологічне середовище). За результатами аналізу з'ясовано, що в разі істотного зменшення кількості джерел значно збільшуються викиди забруднювальних речовин. У 2003-2011 рр. відзначено загальне збільшення рівня техногенного навантаження на повітряний басейн, з 2012 р. - зменшення зі збільшенням викидів від стаціонарних джерел. У разі загального збільшення водозабору відзначено зменшення скидів стічних вод. Рівень техногенного навантаження на поверхневі водні об'єкти істотно зменшився. Максимального техногенного впливу водні об'єкти регіону зазнають від діяльності комунального підприємства Херсона. Максимуми утворення відходів в регіоні зафіксовано у 2012-2014 pр. Переважну кількість у складі утворених відходів становлять відходи IV класу небезпеки. Збільшення нагромаджених відходів становить до 70 тис. т щороку. Кількість нагромаджених відходів останніми роками в 3 рази перевищує показники з утворення. За постійного збільшення нагромаджених відходів на території області рівень техногенного навантаження на геологічне середовище регіону щорічно зростає. Найбільшого навантаження Херсонська область зазнає за показниками скидів стічних вод і утворення відходів. Загалом з 2007 р. встановлено тенденцію до зменшення рівня техногенного навантаження на довкілля. Це зумовлено переважно зменшенням обсягів скидів стічних вод.

Ключові слова: техногенний вплив; складники довкілля; модуль навантаження; забруднювальні речовини.

\section{Вступ}

Херсонська область територіально належить до регіонів Північно-Західного Причорномор'я (ПЗП). Область має унікальний природно-рекреаційний потенціал. При цьому промисловий комплекс Херсонщини формують понад 200 підприємств різних галузей: машинобудування, харчової та переробної, хімічної та целюлозно-паперової, легкої промисловості, електроенергетики. Традиційно пріоритетним вважають суднобудування [14].

В області, як і в інших регіонах ПЗП, існують певні екологічні проблеми, що призводять до виникнення неприятливих екологічних ситуацій. До них належать

- вирішення питань оформлення згідно з чинним законодавством відведення земельних ділянок під полігони твердих побутових відходів (ТПВ) у сільських населених пунктах;

- несприятливі умови для зберігання непридатних для подальшого використання пестицидів і агрохімікатів;

- невідповідність вимогам техногенно-екологічної безпеки очисних споруд і каналізаційних мереж населених пунктів області;

- велика кількість територій і об'єктів ПЗФ області не винесені в натуру, що створює підгрунтя для різних порушень (зміни площі та конфігурації меж, самозахоплення земель ПЗФ, відчуження земель ПЗФ для нецільових потреб або вилучення земельних ділянок) [15].

Об'єкт дослідження - стан довкілля Херсонської області.

Предмет дослідження - методи і засоби оцінювання рівня техногенного навантаження на складники довкілля Херсонської області,що дасть змогу розробити регіональні природоохоронні програми.

Мета роботи - оцінити та проаналізувати особливості техногенного впливу на довкілля Херсонської області із застосуванням окремих модулів техногенного навантаження.

Завдання дослідження: проаналізувати джерела техногенного впливу на довкілля Херсонської області; оцінити рівень техногенного навантаження на деякі складники довкілля регіону.

Наукова новизна отриманих результатів полягає в тому, що вперше розроблено методику, яка дає змогу для Херсонської області виконати комплексне оцінювання рівня техногенного навантаження на регіон за багаторічний період.

Практична значущість результатів дослідження полягає в тому, що їх можна використати під час розроблення регіональних природоохоронних програм для

\section{Інформація про автора:}

Чугай Ангеліна Володимирівна, канд. геогр. наук, доцент, кафедра екології та охорони довкілля. Email: avchugai@ukr.net; https://orcid.org/0000-0002-8091-8430

Цитування за ДСтУ: Чугай А. В. Особливості техногенного впливу на довкілля Херсонської області. Науковий вісник НлтУ України. 2020, т. 30, № 3. С. 60-65.

Citation APA: Chugai, A. V. (2020). Some features of a technogenic impact on the environment of the Kherson Region. Scientific Bulletin of UNFU, 30(3), 60-65. https://doi.org/10.36930/40300311 
зменшення рівня техногенного впливу на деякі природні середовища.

Аналіз літературних джерел. Однією 3 перших спроб виконати комплексне оцінювання техногенного навантаження на довкілля України було створення карти техногенної небезпеки [3]. Згідно з даними цієї карти ще у 2004 р. Херсон характеризувався високим рівнем техногенного навантаження. Для аналізу територій України за показниками антропогенного впливу було застосовано у багатьох роботах методи кластерного аналізу, зокрема в роботі [2]. Аналіз здійснювали за набором показників антропогенного впливу за період 20082011 рр. Згідно з отриманими результатами, Херсонська область увійшла до регіонів зі середнім рівнем антропогенного навантаження.

Питання оцінювання техногенного навантаження на складники довкілля окремих регіонів України є предметом дослідження автора зі співавторами. Так, у роботах $[4,7]$ розглянуто питання оцінювання техногенного навантаження на повітряний басейн і водні об'єкти Херсонської області.

Матеріали і методи досліджсення. Для оцінювання особливостей техногенного впливу на довкілля Херсонської області в роботі застосовано принцип розрахунку модуля техногенного навантаження (MTH) [1]. У попередніх роботах автора $[5,6]$ запропоновано розраховувати окремі модулі навантаження на складники довкілля (модуль техногенного навантаження на повітряний басейн $M_{П Б}$; модуль техногенного навантаження на водні об'єкти $M_{B O}$; модуль техногенного навантаження на геологічне середовище $\left.M_{\Gamma C}\right)$. Цей підхід застосовано і в цьому дослідженні. Оцінювання виконано із застосуванням даних про показники викидів, скидів забруднювальних речовин (ЗР), утворення та нагромадження відходів.

\section{Результати дослідження та їх обговорення}

Херсонська область за обсягом викидів ЗР в атмосферне повітря, за даними [15], посідає п'яте місце серед регіонів України. Переважними джерелами викидів ЗР є пересувні джерела. Серед стаціонарних джерел основними забруднювачами атмосферного повітря $\epsilon$ підприємства Херсона. 32012 р. за істотного зменшення кількості підприємств в регіоні (на порядок), які здійснювали викиди ЗР, відзначено значне збільшення викидів ЗР.

На рис. 1 наведено результати розрахунку $M_{П ь}$ для Херсонської області за даними Екологічних паспортів про викиди ЗР. 32016 р. не було даних про викиди ЗР від пересувних джерел. 32012 р. обсяги викидів від пересувних джерел постійно знижувались, і за останні два роки їх внесок у формування загального рівня забруднення повітряного басейну в регіоні становив в середньому 86,5 \%. Тому для розрахунку викидів у 20162018 рр. взято такий рівень забруднення пересувними джерелами від загального обсягу викидів. Як видно, у 2003-2011 рр. відбулося загальне збільшення рівня техногенного навантаження на повітряний басейн Херсонської області внаслідок збільшення викидів ЗР, передусім, від пересувних джерел.

32012 р. значення $M_{П ь}$ зменшувалось, хоча виявлено поступове збільшення викидів від стаціонарних джерел. У 2016-2018 р. за наявними даними навантаження знову збільшилось.

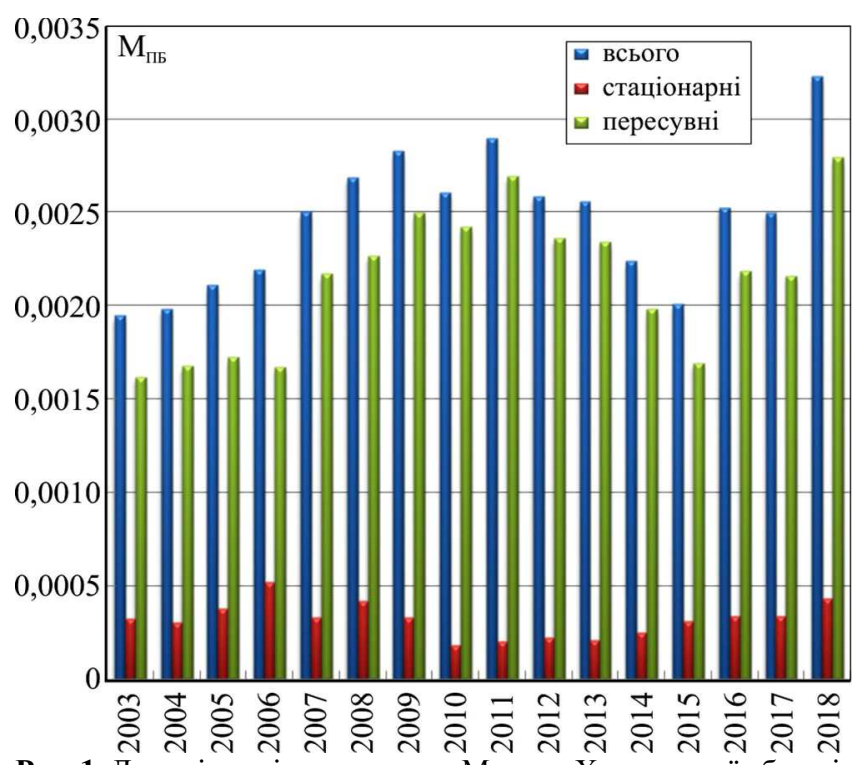

Рис. 1. Динаміка зміни показника $\mathrm{M}_{\text {Пь }}$ для Херсонської області у 2003-2018 pp.

За даними [15] у 2017 р. було зареєстровано 1218 водокористувачів. Основними забруднювачами водних об'єктів були 7 підприємств, а саме: завод "Палада" (м. Херсон); ПАТ "Судноплавна компанія "Укррічфлот", філія "Херсонський річковий порт"; ККУП "Джерело" Каланчацької селищної ради; ТОВ "Рис України"; ПП "Жукова" (с. Олексіївка); ФГ "Південне" (с. Олексіївка); КП "Очисні споруди" Скадовської міської ради [15].

Було проаналізовано динаміку водозабору і скидів зворотних вод у Херсонській області за багаторічний період (рис. 2 і 3). Аналіз обсягів водозабору по регіону (див. рис. 2) показує, що за період дослідження відбувається постійне збільшення показників 3 вираженим максимумом у 2018 р. (збільшення порівняно з 2017 р. в 1,7 раза).

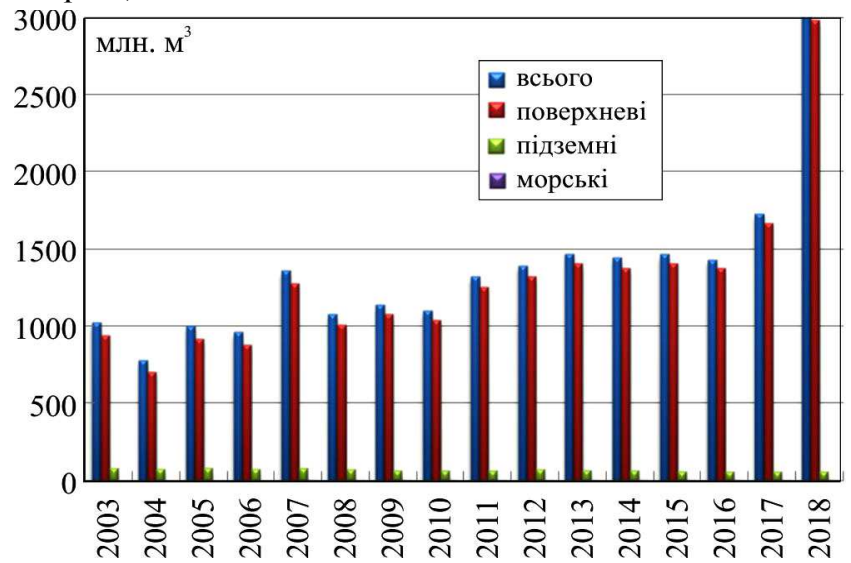

Рис. 2. Динаміка водозабору у Херсонській області у 20032018 pp. [10-15]

Найбільший водозабір здійснюють 3 поверхневих водних джерел, найменший - 3 морських. Окрім цього, за наявними даними до 2007 р. забір морських вод не здійснювали. Забір підземних вод за період дослідження зменшився на $25 \%$.

За загального збільшення водозабору відбувається зменшення скидів стічних вод (СВ) (рис. 3). У 20052006 рр. обсяг скидів зменшився майже вдвічі, і ця тенденція триває. Максимальний обсяг скидів СВ здійснюють у поверхневі водні об'єкти. У загальному обсязі за ступенем очищення переважають постійно нормативно 
чисті СВ (без очищення). 3 року в рік змінюється частка забруднених СВ. В окремі роки (2003 і 2006 рр.) їх частка становила близько $30 \%$.

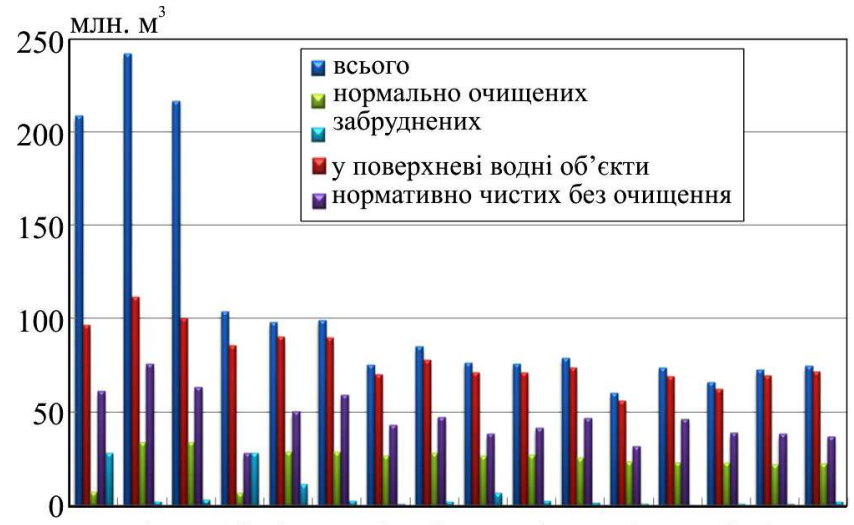

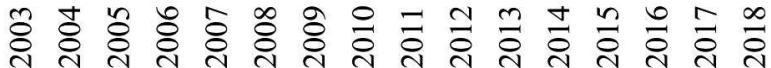

Рис. 3. Динаміка скиду зворотних вод у Херсонській області у 2003-2018 pp. [10-15]

За даними Регіональних доповідей і Екологічних паспортів Херсонської області було розраховано показник $M_{B O}$ за показниками скидів СВ і ЗР у їх складі (рис. 4). Аналіз наведеного рисунка показує, що рівень

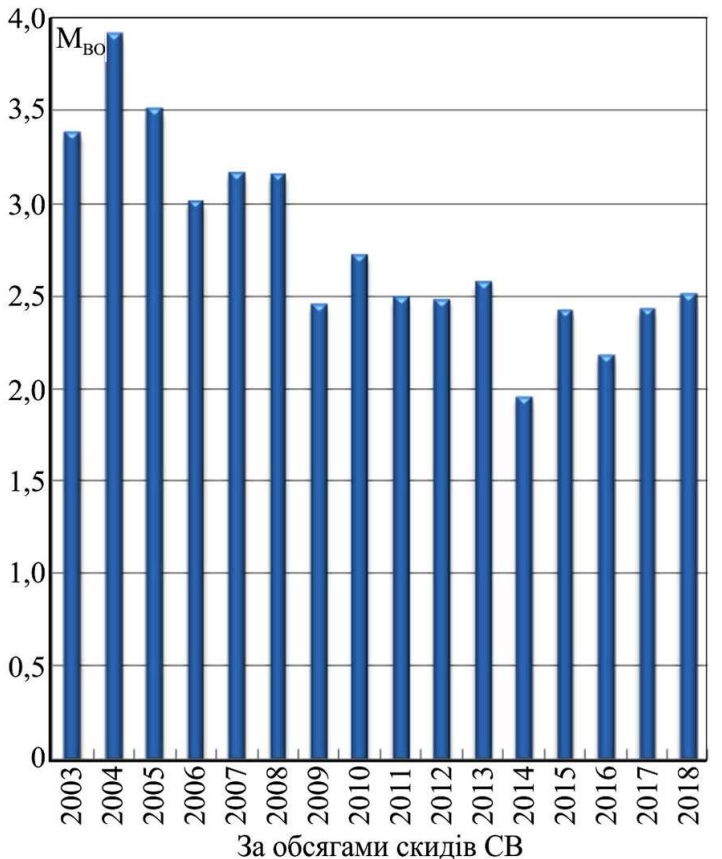

За обсягами скидів СВ

Рис. 4. Значення показника $\mathrm{M}_{\mathrm{BO}}$ Херсонської області у 2003-2018 pp.

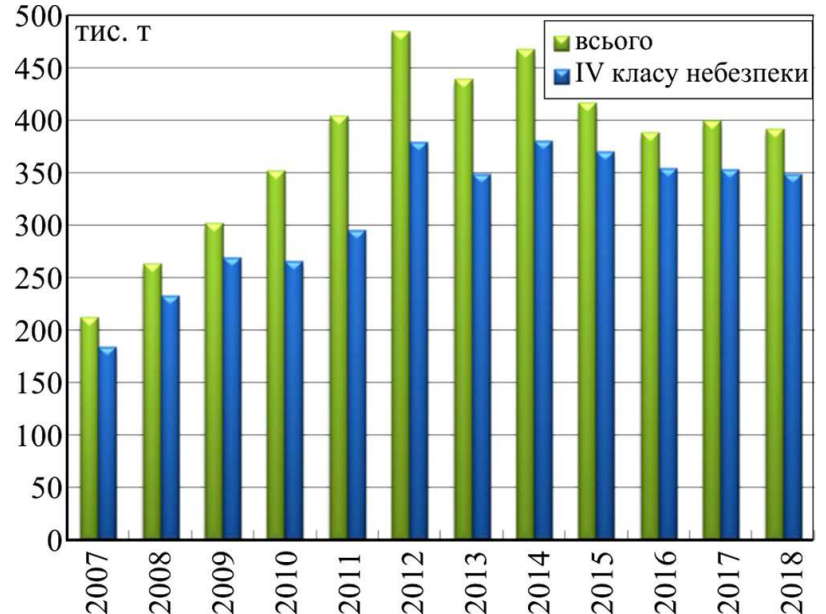

Рис. 5. Динаміка утворення відходів у Херсонській області у 2007-2018 pp. техногенного навантаження на поверхневі водні об'єкти за обома показниками за період дослідження істотно зменшився. Значення $M_{B O}$ за обома характеристиками зменшилось майже на $30 \%$, як і обсяги скидів CВ у регіоні. Результати аналізу показують, що скиди СВ від ВУВКГ Херсона перевищують відповідні по інших підприємствах області на 1-2 порядки. Серед інших підприємств значні обсяги скидів відзначено для ТОВ "Рис України". Загалом майже по всіх розглядуваних підприємствах відзначено зменшення скидів СВ за період дослідження.

На території Херсонської області налічується 100 б'єків утворення відходів і 8 об'єктів оброблення та утилізації відходів [13]. У сфері поводження з ТПВ склалася критична ситуація. Щороку в регіоні утворюється понад 250 тис. т ТПВ. Згідно 3 даними інвентаризації місць, видалення ТПВ на території області розташовано 329 таких об'єктів, 3 них тільки 73 паспортизовані і 77 експлуатуються за наявності документації на право користування земельними ділянками [14]. За даними Регіональних доповідей і Екологічних паспортів було проаналізовано інформацію щодо обсягів утворення та нагромадження відходів у регіоні.

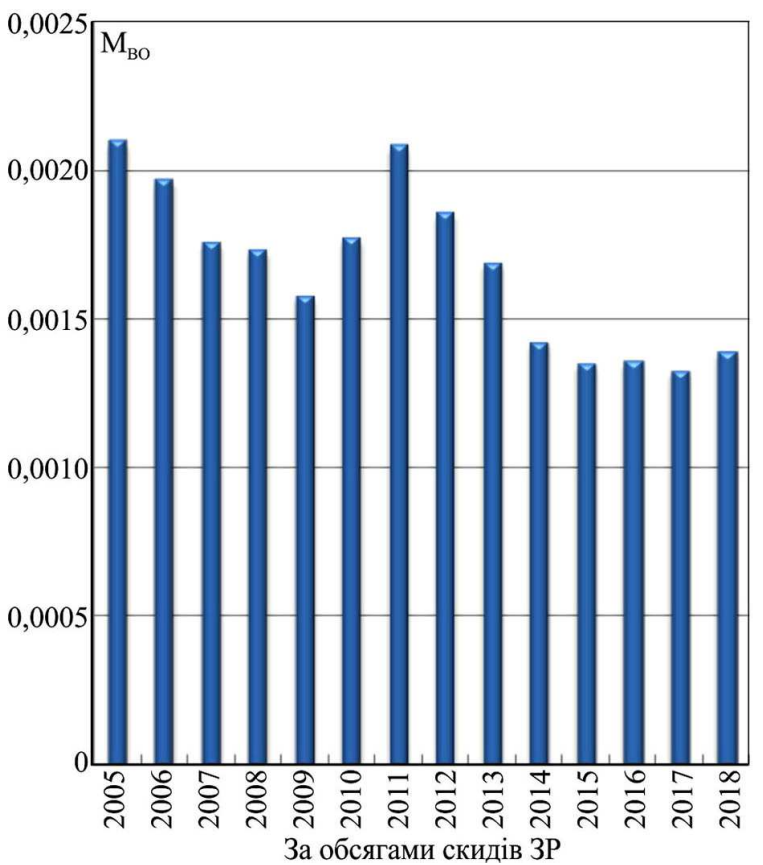

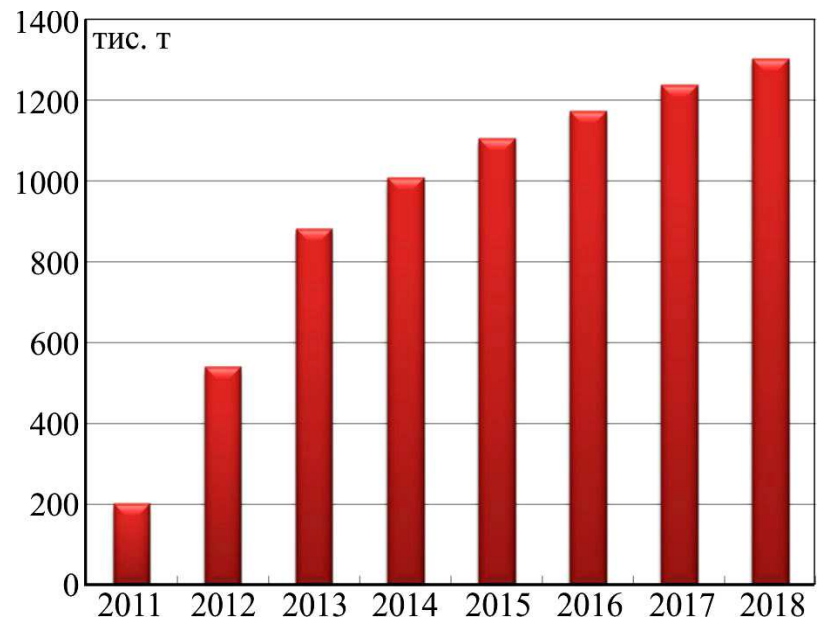

Рис. 6. Обсяги нагромаджених відходів у Херсонській області у 2011-2018 pp. 
На рис. 5 наведено динаміку зміни кількості утворення відходів у Херсонській області. Варто зазначити, що фактичні дані в окремі роки були відсутні. Тому 3 урахуванням наявних залежностей вони були проінтерпольовані. Було визначено загальний обсяг утворених відходів у 2010 р. (з урахуванням фактичного збільшення кількості у 2007-2009 рр.) і обсяг відходів IV класу небезпеки у 2018 р. (за розрахунками у 2015-2017 pp. ця величина в середньому становила 89 \% від загальної кількості відходів). Максимуми утворення відходів у регіоні зафіксовано у 2012-2014 рр. До 2012 р. відзначено поступове істотне збільшення загального обсягу утворених відходів, у 2015-2018рр. - деяке зменшення. Упродовж останніх років ця величина майже не змінювалась. Переважну кількість у складі утворених відходів у всі роки утворюють відходи IV класу небезпеки.

Інформація щодо кількості нагромаджених відходів в області (рис. 6) була наявна тільки з 2011 р., і дані за 2018 р. були також проінтерпольовані з урахуванням тенденцій нагромадження за останні роки. Як видно, у 2011-2013 рр. відбулось стрімке збільшення обсягів нагромаджених відходів на території Херсонської області (у 4 рази). 32014 р. ця тенденція подовжувалась, i впродовж останніх років збільшення нагромаджених відходів становить до 70 тис. т щороку. Також обсяг нагромаджених відходів за останні роки в 3 рази перевищує показники з їх утворення. Це значно нижче порівняно з іншими регіонами ПЗП, де відповідні показники відрізнялись на порядок.

Було розраховано показник $M_{\Gamma C}$ за наявними даними для Херсонської області. Результати розрахунку наведено на рис. 7. Встановлено, що за постійного збільшення нагромаджених відходів на території Херсонської області рівень техногенного навантаження на геологічне середовище регіону щорічно зростає.

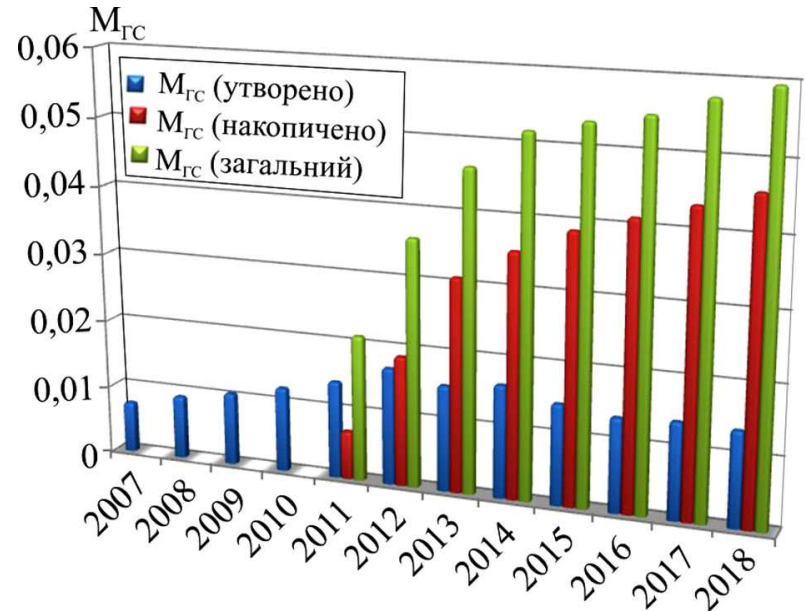

Рис. 7. Значення показника $\mathrm{M}_{\Gamma \mathrm{C}}$ Херсонської області у 20072018 pp.

Особливістю прибережної зони Херсонської області $\epsilon$ активний розвиток інженерно-геологічних процесів, пов'язаних з техногенним впливом на геологічне середовище (ГС): підтоплення зрошувальних масивів і населених пунктів, активізація зсувів у береговій зоні моря i в долинах річок та балок, просадка лесових масивів, просідання та осідання земної поверхні внаслідок підробок гірничими виробками та ін. Одним із небезпечних процесів, який характеризується широким розповсюдженням на досліджуваній території та зумовлений техногенною діяльністю, є підтоплення грунтовими во- дами, який супроводжується зміною фізико-механічних властивостей грунтів, зменшенням їх несучої здатності та природного грунтового опору, активізацією небезпечних геологічних процесів (карст, зсуви, суфозія), що призводить до непередбачених осідань будівель і споруд та їх руйнування. У формуванні процесу підтоплення велике значення, поряд 3 природними, мають техногенні фактори, а саме: зарегульованість річкового стоку; іригація земель; втрати з мереж водопостачання та водовідведення; освоєння та забудова територій тощо. Станом на 2018 р. підтоплення охоплює: Скадовський район - $47 \%$, Голопристанскьий район - $54 \%$, Білозерський район - 57 \% і Каланчацький район - $75 \%$ від загальної площі області. Зрошене землеробство набуло широкого розповсюдження на території досліджень, що зумовило порушення загального водного балансу, змін гідрогеологічних умов, а також сприяло підтопленню, ерозії, засоленню, карсту, просіданню лесових грунтів тощо [17].

Техногенний вплив на ГС здійснюється також під час експлуатації родовищ підземних вод (ПВ). Херсонська міська агломерація розташована на правому високому березі Дніпра, але, незважаючи на наявність i доступність до поверхневих джерел водопостачання, система централізованого водопостачання базується на ПВ. Основна частина прісних ПВ зосереджена переважно в сарматському водоносному комплексі міоцену. Цей комплекс широко розгалужений по території Херсонської області та забезпечує майже стовідсотковий видобуток ПВ. Загальна кількість водозабірних свердловин завглибшки 80-100 м - понад 150, але тільки приблизно 50 \% від цієї кількості є функціональними. ПВ надходять у водопровідну мережу, протяжність якої сягає майже 900 км. Водопостачання здійснюється комплексом споруд, що виконують задачі водопостачання, тобто одержання води з природних джерел, ії очищення, транспортування та подачу споживачам. Під час забору води 3 підземних джерел у схемі водопостачання відсутні очисні споруди, тому що ПВ не мають потреби в очищенні. Знезараження води здійснюється рідким хлором на хлораторних станціях (насосна станція № 1, 2, 4), гіпохлоритом натрію (насосна станція № 3) i ультрафіолетовим випромінювачем у мікрорайоні "Корабел". Локальні артезіанські свердловини, які розташовані в місті та селищах Комишани, Антонівка, Текстильників, Степанівка, подають воду безпосередньо у водопровідну мережу для водопостачання окремих груп будинків.

Варто зазначити, що понтичний водоносний горизонт (ВГ), який до кінця 1960-х років використовувався для скидання господарсько-побутових стоків, є джерелом забруднення, оскільки забруднені води по затрубному простору свердловин, неприданих для експлуатації, перетікають у верхньосарматський ВГ. ПВ верхньосарматського ВГ забруднені нітратами (до 250 мг/дм ${ }^{3}$ за норми 45 мг/дм $\left.{ }^{3}\right)$. За даними МКП "ВУВКГ м. Херсон" за 2015 р. для окремих свердловин значення загальної жорсткості змінюється від 7,1 ммоль/дм ${ }^{3}$ (ПО "Холодильник") до 38,8 ммоль/дм ${ }^{3}$ (вул. Червоноармійська, $2-\mathrm{a})$, середнє значення $(n=25)-11,2$ ммоль/дм ${ }^{3}$, тобто набагато перевищує максимальну фізіологічну норму 7,0 ммоль/дм ${ }^{3}$. Однак у деяких свердловинах значення загальної жорсткості у межах 7,1-9,8 ммоль/дм ${ }^{3}$, що дещо нижче від нормативу для питної води 3 колодязів та 
каптажів ( $\leq 10,0$ ммоль/дм $\left.{ }^{3}\right)$. Значення сухого залишку змінюється від 1026,6 мг/дм ${ }^{3}$ (вул. Комсомольська, 66а) до 4815,5 мг/дм ${ }^{3}$ (вул. Червоноармійська, 2-а), середнє значення $(n=15)-2260,0$ мг/дм ${ }^{3}$, тобто набагато вище від максимальної фізіологічної норми $\left(500,0\right.$ мг/дм $\left.{ }^{3}\right)$. Але в окремих свердловинах значення сухого залишку у межах 1026,6-1246,8 мг/дм ${ }^{3}$, що дещо нижче від нормативу для питної води з колодязів і каптажів ( $\leq 1500,0$ мг/дм $\left.{ }^{3}\right)$.

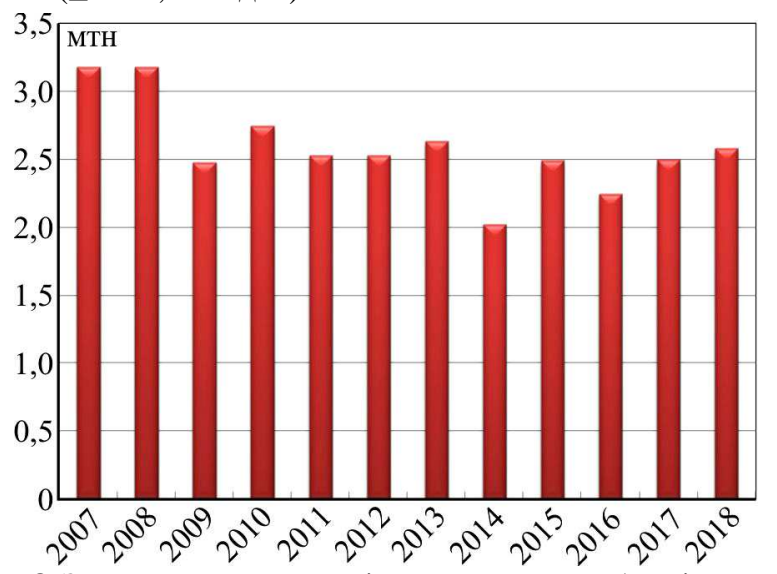

Рис. 8. Значення МТН на довкілля Херсонської області у 2007$2018 \mathrm{pp}$.

На підставі отриманих даних виконано загальну оцінку техногенного навантаження на складники довкілля Херсонської області (рис. 8). Найбільше навантаження Херсонська область зазнає за показниками скидів СВ і утворення відходів. За класифікацією авторів роботи [8] цей регіон можна віднести до переліку техногенно напружених регіонів України. Загалом 3 2007 р. триває тенденція до зменшення рівня техногенного навантаження на довкілля регіону. Це зумовлено передусім зменшенням обсягів скидів $\mathrm{CB}$, які дають найбільший внесок у формування загального рівня техногенного впливу. Отримані результати свідчать про деяке покращення стану довкілля у Херсонській області і відрізняються від інших регіонів ПЗП, де значення $M T H$ за багаторічний період загалом збільшилось.

\section{Висновки}

Виконані дослідження щодо особливостей техногенного навантаження на довкілля Херсонської області дають змогу зробити такі висновки:

- у 2003-2011 pр. відзначено загальне збільшення рівня техногенного навантаження на повітряний басейн, з 2012 р. зменшення зі збільшенням викидів від стаціонарних джерел;

- за загального збільшення водозабору відзначено зменшення скидів CB; рівень техногенного навантаження на поверхневі водні об'єкти істотне зменшився; максимального техногенного впливу водні об'єкти регіону зазнають від діяльності підприємств житлово-комунального господарства Херсона;
- максимуми утворення відходів в регіоні відзначено у 2012 2014 рр.; збільшення нагромаджених відходів становить до 70 тис. т щороку і їх кількість за останні роки в 3 рази перевищує показники 3 утворення, що позначається на збільшенні навантаження на геологічне середовище регіону;

- загалом найбільшого навантаження Херсонська область зазнає за показниками скидів СВ і утворення відходів; 3 2007 р. відзначено тенденцію до зменшення рівня техногенного навантаження на довкілля, що зумовлено переважно зменшенням обсягів скидів СB;

- одним із небезпечних процесів, який характеризується широким розповсюдженням на досліджуваній території та зумовлений техногенною діяльністю, є підтоплення грунтовими водами, який супроводжується активізацією небезпечних геологічних процесів.

\section{References}

1. Adamenko, O. M., \& Rudko, H. I. (1998). Ecological geology. Kyiv: Manuskrypt. [In Ukrainian].

2. Baluieva, O. V., \& Chynkuliak, N. M. (2013). Cluster analysis of the territories of Ukraine according to indicators of anthropogenic pressures on the environment. Efektyvna ekonomika, 12. Retrieved from: http://www.economy.nayka.com.ua/?op=1\&z=2574. [In Ukrainian].

3. Baranovskyi, V. A., Shyshchenko, P. H., \& Dmytruk, O. Iu. (2004). Ukraine. Man-made hazard, scale 1: 3000000. Kyiv. [In Ukrainian].

4. Chugai, A. (2020). Quality assessment and a level of technogenic load on the surface waters of the Kherson region. Environmental Problems, 5(1), 44-49. https://doi.org/10.23939/ep2020.01.044

5. Chugai, A. V. (2020). Evaluation of technogeneous load on the environmental components of the Odessa region. Ekolohichni na$u k y, 28,102-110$. [In Ukrainian].

6. Chugai, A. V. (2020). Technogenic loads on the environment the Mykolaiv region. Visnyk Vinnytskoho politekhnichnoho instytutu, 2, 27-33. https://doi.org/10.31649/1997-9266-2020-149-2-27-33

7. Chugay, A., \& Borovska, H. (2020). Evaluation of technogenic load on the air pool of the Kherson region. Scientific Light, 33(1), $37-42$.

8. ECOLOG. (2017). Retrieved from: http://ecolog.at.ua.

9. Ekolohichnyi pasport Khersonskoi oblasti. 2005 rik. (2006). Ecological passport of Kherson region. Kherson. [In Ukrainian].

10. Ekolohichnyi pasport Khersonskoi oblasti. 2006 rik. (2007). Ecological passport of Kherson region. Kherson. [In Ukrainian].

11. Ekolohichnyi pasport Khersonskoi oblasti. 2012 rik. (2013). Ecological passport of Kherson region. Kherson. [In Ukrainian].

12. Ekolohichnyi pasport Khersonskoi oblasti. 2015 rik. (2016). Ecological passport of Kherson region. Kherson. [In Ukrainian].

13. Ekolohichnyi pasport Khersonskoi oblasti. 2018 rik. (2019). Ecological passport of Kherson region. Kherson. [In Ukrainian].

14. Promyslovyi potentsial. (2019). Retrieved from: https://khoda.gov.ua/promislovij-potencD196al.

15. Regional report on the state of the environment in the Kherson region in 2017. (2018). Kherson. [In Ukrainian].

16. Report on the state of the environment of the Kherson region for 2007. (2008). Kherson. [In Ukrainian].

17. The state and quality of the natural environment of the coastal zone of the North-Western Black Sea coast. (Safranova, T. A., \& Chugai, A. V. Scientific Ed.). Kharkiv: FOP Panov, A. M. [In Ukrainian].

A. V. Chugai

Odessa State Ecological University, Odessa, Ukraine

\section{SOME FEATURES OF A TECHNOGENIC IMPACT ON THE ENVIRONMENT OF THE KHERSON REGION}

Kherson Region territorially belongs to the regions of the Northwest Black Sea Coast. Kherson Region has a unique recreational potential. At the same time the industrial complex of the region consists of more than 200 enterprises of various industries. Certain environmental problems exist in the region, which leads to unfavourable environmental situations (allotting the land plots for landfills, the conditions and the state of the unusable pesticides storage, treatment facilities and settlements sewerage networks of the region, etc.). To assess the features of a technogenic impact on the environment of Kherson Region, the principle of calculating the 
technogenic load module is used in the work. Separate modules for the components of the environment such as the air basin, water bodies, and the geological environment were calculated. The analysis showed that with a significant reduction in the number of sources there is a significant increase in pollutant emissions. In 2003-2011 a general increase in the level of a technogenic load on the air basin was determined, since 2012 there has been a decrease with increasing emissions from the stationary sources. There is a decrease in wastewater discharges with an overall increase in water intake. The level of a technogenic load on the surface water bodies has decreased significantly. Water bodies in the region receive maximum technogenic impact from the activities of the utility company in the city of Kherson. Maximum waste generation in the region was observed in 2012-2014. The predominant amount of generated waste is the waste of the fourth hazard class. The increase in accumulated waste amounts to 70 thousand tons annually. The amount of accumulated waste in recent years is 3 times higher than the generation indexes. With a constant increase of the accumulated waste in the region, the level of a technogenic load on the geological environment of the region is growing every year. To conclude, Kherson Region receives the greatest load in terms of wastewater discharges and waste generation. In general, since 2007 there has been a tendency to reduce a level of a technogenic load on the environment. This is mainly due to the reduction of wastewater discharges.

Keywords: technogenic impact; components of the environment; load module; pollutants. 